\title{
Reclassification of Bacteroides levii (Holdeman, Cato, and Moore) in the Genus Porphyromonas, as Porphyromonas levii comb. nov.
}

\author{
HAROUN N. SHAH, ${ }^{1 *}$ MATTHEW D. COLLINS, ${ }^{2}$ INGAR OLSEN, ${ }^{3}$ \\ BRUCE J. PASTER, ${ }^{4}$ AND FLOYD E. DEWHIRST ${ }^{4}$ \\ Department of Microbiology, Eastman Dental Institute, University of London, London, ${ }^{1}$ and Department of \\ Microbiology, Institute of Food Research, Reading Laboratory, Reading, ${ }^{2}$ United Kingdom; Department \\ of Oral Biology, Dental Faculty, University of Oslo, Oslo, Norway ${ }^{3}$; and Department of \\ Molecular Genetics, Forsyth Dental Center, Boston, Massachusetts ${ }^{4}$
}

\begin{abstract}
The genus Bacteroides was recently redefined to include only the type species Bacteroides fragilis and closely related taxa. Most other species that were previously designated Bacteroides have been reclassified in new genera. The taxonomic position of Bacteroides levii (Holdeman, Cato, and Moore) has remained incertae sedis. On the basis of biochemical, chemical and comparative 16S rRNA sequence analyses, this species shares a high degree of similarity with members of the genus Porphyromonas. We therefore formally propose that Bacteroides levii (Holdeman, Cato, and Moore) be reclassified in the genus Porphyromonas, as Porphyromonas levii comb. nov.
\end{abstract}

The taxonomy of the genus Bacteroides has undergone major revision in the past few years $(25,26)$. The genus as described in Bergey's Manual of Systematic Bacteriology (8) comprises an ill-defined association of obligately anaerobic, gram-negative, nonsporing, rod-shaped bacteria. Extensive chemotaxonomic (e.g., porphyrin characterization [31], multilocus enzyme electrophoresis [37], lipid analyses [1, 27]) and genotypic (e.g., DNA base composition $[30,36,38])$ studies performed in the late 1970 s through the 1980 s revealed marked heterogeneity within the genus. On the basis of these studies Shah and Collins (3335) proposed that the genus Bacteroides be divided into three major groups: (i) a redefined genus Bacteroides, restricted to members of the $B$. fragilis group; (ii) genus Prevotella, consisting of moderately saccharolytic, bile-sensitive, predominantly oral species, such as P. melaninogenica; and (iii) genus Porphyromonas, for the pigmented species $P$. asaccharolytica and close relatives. A number of predominantly monospecific genera (e.g., Anaerorhabdus [32], Catonella [21], Dialister [21], Fibrobacter [20], Hallella [21], Johnsonella [21], Megamonas [28], Mitsuokella [29], Oribaculum [21], Rikenella [4], Ruminobacter [40], Sebaldella (31), and Tissierella [3]) have been described for some of the species that do not conform to the description of these three genera. The species $B$. levii (formerly $B$. melaninogenicus subspecies levii) $(10,11)$ was excluded from the genus Bacteroides as redefined by Shah and Collins (34), and its taxonomic position is currently incertae sedis.

B. levii resembles Porphyromonas species in forming pigmented colonies on blood agar and possessing similar dehydrogenase profiles (30). However, unlike the majority of porphyromonad species, $B$. levii is weakly saccharolytic (8). Because of the placement of "saccharolytic pigmented" species in the genus Prevotella and "non-fermentative pigmented" species in the genus Porphyromonas, the taxonomic position of the weakly saccharolytic $B$. levii has thus remained unresolved. Recently several new asaccharolytic pigmented species such as $P$. circumdentaria (18), $P$. cangingivalis, $P$. cansulci (2), $P$. gingivicanis, and $P$. crevioricanis $(7)$ and the weakly saccharolytic

\footnotetext{
* Corresponding author. Mailing address: Department of Microbiology, Eastman Dental Institute, University of London, 256 Gray's Inn Road, London WC1X 8LD, United Kingdom. Phone: +0171-9151052. Fax: +0171-915-1127. Electronic mail address: hshah@eastman. UCL.AC.UK.
}

$P$. macacae (syn. $P$. salivosa) (17) were assigned to the genus Porphyromonas. The mol\% $\mathrm{G}+\mathrm{C}$ range of the resulting enlarged genus Porphyromonas is now approximately 40 to $55 \%$ and species characteristically produce complex metabolic end product profiles that include acetic, propionic, butyric, isovaleric, phenylacetic, or succinic acids. B. levii (46 to $48 \mathrm{~mol} \%$ $\mathrm{G}+\mathrm{C}$ ) produces significant levels of $n$-butyric and acetic acids and in this respect is compatible with some members of the genus Porphyromonas (Table 1). The highly distinctive feature of 13-methyl-tetradecanoic acid $\left(i-\mathrm{C}_{15: 0}\right)$ as a major long-chain cellular fatty acid of porphyromonads is also produced by $B$. levii (Table 1). By contrast, Bacteroides and Prevotella species possess 12-methyl tetradecanoic acid $\left(a i-C_{15: 0}\right)$ as their major long-chain cellular fatty acid $(1,34,35)$ and produce a simpler metabolic end product profile of mainly acetic and succinic acids.

Recently, 16S rRNA gene sequencing has confirmed the validity of restricting the genus Bacteroides to the $B$. fragilis group of species $(2,22-24)$ and in the main support the taxonomic restructuring proposed by Shah and Collins (33-35). In particular, these studies show that Prevotella and Porphyromonas are phylogenetically distinct and that the weakly saccharolytic pigmented species $B$. levii is also a member of the genus Porphyromonas (Fig. 1). Thus on the basis of the phylogenetic evidence and the phenotypic distinctiveness of $B$. levii, we formally propose the reclassification of this species in the genus Porphyromonas. Since $B$. levii is weakly saccharolytic, and all Porphyromonas species produce malate and glutamate dehydrogenases but some species (mainly of animal origin) additionally possess glucose-6-phosphate and 6-phosphogluconate dehydrogenases, we further propose that the description of the genus Porphyromonas be amended accordingly.

Description of Porphyromonas levii (Holdeman, Cato, and Moore) comb. nov. The description below is based on previous studies $(6-19,27,37,41)$ and our own observations:

Gram-negative, obligately anaerobic, nonsporeforming, nonmotile rods or coccobacilli. Cells in broth are 0.5 to 1 by 2 to $5 \mu \mathrm{m}$. Cells from solid media are coccobacilli or short rods. Colonies on blood agar plates are smooth, shiny, convex, and 1 to $2 \mathrm{~mm}$ in diameter and darken from the edge of the colony toward the center between 4 and 8 days. Protoheme is the major porphyrin produced, but traces of protoporphyrin also occur. Succinate stimulates growth and can replace the requirement for protohaem. Few sugars such as glucose and 
TABLE 1. Salient features of current members of the genus Porphyromonas and identification of $P$. levii from among these species ${ }^{a}$

\begin{tabular}{|c|c|c|c|c|c|}
\hline $\begin{array}{l}\text { Porphyromonas } \\
\text { species }\end{array}$ & $\begin{array}{l}\mathrm{Mol} \% \\
\mathrm{G}+\mathrm{C}\end{array}$ & $\begin{array}{l}\text { G6PDH and } \\
6 \text { PGDH }^{b}\end{array}$ & $\begin{array}{l}\text { Major acid end } \\
\text { products }^{c}\end{array}$ & Major cellular fatty acids $(\%)^{d}$ & Important phenotypic tests \\
\hline P. asaccharolytica ${ }^{\mathrm{T}}$ & $52-54$ & - & $\mathrm{A}, \mathrm{P}, \mathrm{B}, \mathrm{iB}, \mathrm{iV}$ & $i-C_{15: 0}(60-87)$ & $\alpha$-Fucosidase \\
\hline P. cangingivalis & & + & A, B & $i-\mathrm{C}_{15: 0}(32)$, ai- $\mathrm{C}_{15: 0}$ (12) & Catalase \\
\hline P. canoris & $49-51$ & + & $\mathrm{A}, \mathrm{P}, \mathrm{iV}, \mathrm{S}$ & $i-\mathrm{C}_{15: 0}(37), 3-\mathrm{OH}, i-\mathrm{C}_{17: 0}(12)$ & $\begin{array}{l}\text { Chymotrypsin, } \beta \text {-galactosidase, } N \text {-acetyl- } \\
\beta \text {-glucosaminidase }\end{array}$ \\
\hline P. cansulci & $49-51$ & - & $\mathrm{A}, \mathrm{P}, \mathrm{B}, \mathrm{iV}, \mathrm{S}$ & $i-\mathrm{C}_{15: 0}(49), \mathrm{C}_{16: 0}(12)$ & Catalase \\
\hline$P$. circumdentaria & $40-42$ & - & $\mathrm{A}, \mathrm{B}, \mathrm{iV}, \mathrm{S}$ & $i-\mathrm{C}_{15: 0}(56), \mathrm{C}_{16: 0}$ & Catalase \\
\hline$P$. crevioricanis & $44-45$ & - & $A, P, i V(S)$ & ND & $\mathrm{HA}^{e}$ activity \\
\hline P. endodontalis & $49-51$ & - & A, B & $i-\mathrm{C}_{15: 0}(30-43)$ & Indole produced; negative (most tests) \\
\hline P. gingivalis & $47-50$ & - & $\mathrm{A}, \mathrm{B}, \mathrm{iV}, \mathrm{Pa}$ & $\begin{array}{l}3-\mathrm{OH}, i-\mathrm{C}_{17: 0}(20-30) \\
i-\mathrm{C}_{15: 0}(16-56) \\
a i-\mathrm{C}_{15: 0}(5-21), 3-\mathrm{OH}, i-\mathrm{C}_{17: 0}(30-34)\end{array}$ & $\begin{array}{l}\text { HA thorescence colonie: } \\
\text { Cysteine proteinase }\end{array}$ \\
\hline$P$. gingivicanis & $41-42$ & - & A, B, iV & ND & \\
\hline P. levii & $46-48$ & $\mathrm{~V}$ & A, B & $i-\mathrm{C}_{15: 0}(22-32), a i-\mathrm{C}_{15: 0}(7-35)$ & $\begin{array}{l}\text { Acid from: glucose and lactose, gelatin } \\
\text { (liquified) }\end{array}$ \\
\hline P. macacae & $42-45$ & $\mathrm{~V}$ & $\mathrm{PA}, \mathrm{B}, \mathrm{iV}, \mathrm{S}, \mathrm{Pa}$ & $i-\mathrm{C}_{15: 0}(13-42), a i-\mathrm{C}_{15: 0}(25-30)$ & $\begin{array}{l}\text { Acid from glucose, lactose and mannose; } \\
\text { lipase, proteinase, } \alpha \text {-galactosidase }\end{array}$ \\
\hline
\end{tabular}

${ }^{a}$ Data compiled from references $1,4,7-11,19,27,30,39$, and 41 .

${ }^{b}$ G6PDH, glucose-6-phosphate dehydrogenase; 6PGDH; 6-phosphogluconate dehydrogenase; $\mathrm{V}$, present in some strains.

${ }^{c}$ Acid end products (concentrations $>10^{2} \mathrm{M}$ are considered significant): $\mathrm{A}$, acetic; $\mathrm{P}$, propionic; $\mathrm{nB}, n$-butyric; iV, isovaleric; $\mathrm{S}$, succinic acids; $\mathrm{Pa}$, phenylacetic acid. Acids in parenthesis are present in some strains as major acid end products.

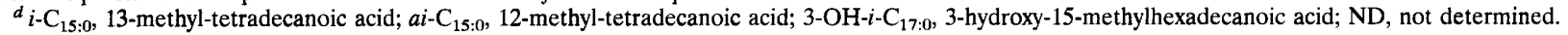

e HA, hemagglutinin.

lactose are weakly fermented. Most other commonly occurring sugars such as arabinose, cellobiose, maltose, melezitose, melibiose, raffinose, rhamnose, ribose, salicin, sucrose, trehalose, and xylose are not fermented. Growth is markedly af-

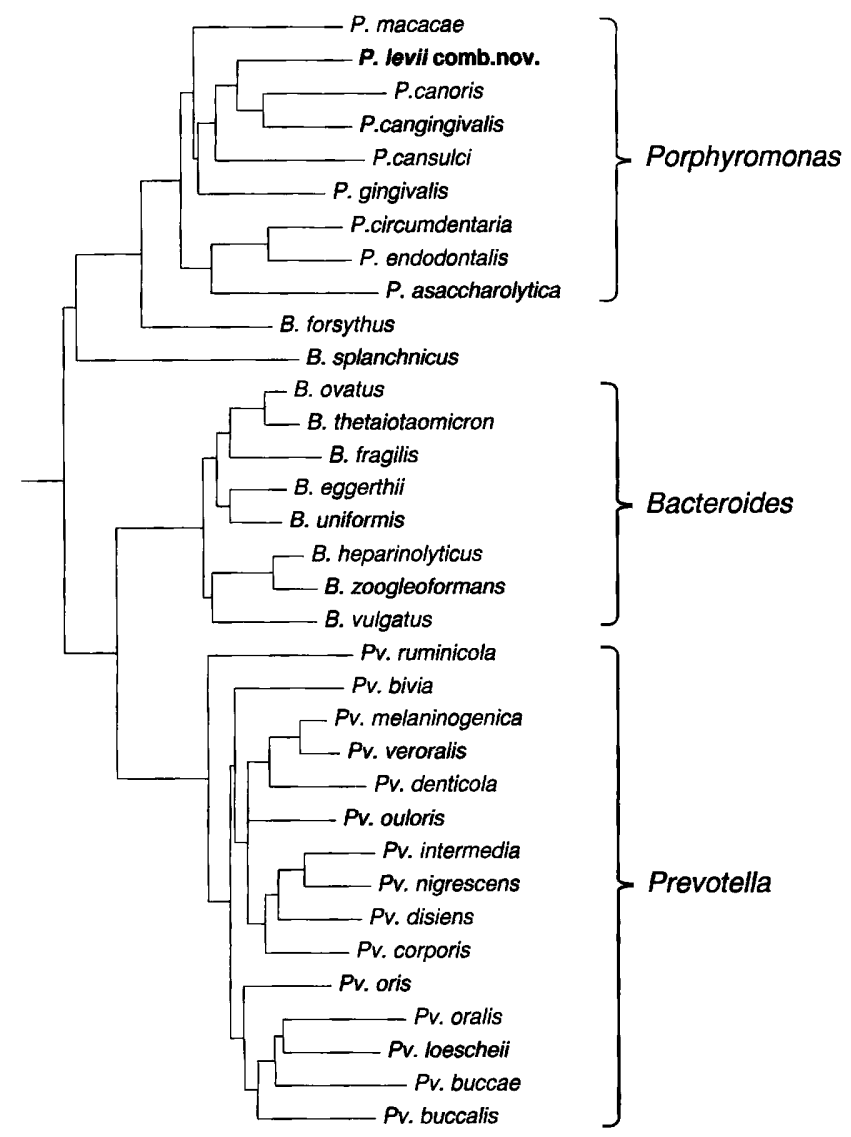

FIG. 1. Unrooted phylogenetic tree based on 16S rRNA sequences showing the placement of $B$. levii within the genus Porphyromonas. fected by the presence of protein hydrolysates such as trypticase, proteose peptone, and yeast extract. Some amino acids such asparagine, tryptophan, and phenylalanine and glutamine are utilized.

Major fermentation products from BM or PYG medium are $n$-butyric and acetic acids; lower levels of propionic, isobutyric, isovaleric, and succinic acids are also produced. Indole is not produced. Nitrate is not reduced to nitrite. Starch and esculin are not hydrolyzed. Malate and glutamate dehydrogenases are present; some strains possess glucose-6-phosphate and 6-phosphogluconate dehydrogenase.

The principal respiratory quinones are menaquinones. Both nonhydroxylated and 3-hydroxylated fatty acids are present. The nonhydroxylated fatty acids are composed of predominantly $i s o$-methyl branched types, with $i-\mathrm{C}_{15: 0}$ acid predominating.

The DNA base compositions ranges between 46 and 48 $\mathrm{mol} \% \mathrm{G}+\mathrm{C}$

The type strain is strain ATCC 29147.

\section{REFERENCES}

1. Brondz, I., I. Olsen, M. Haapasalo, and A. van Winkelhoff. 1991. Multivariate analyses of fatty acid data from whole-cell methanolysates of Prevotella, Bacteroides and Porphyromonas spp. J. Gen. Microbiol. 137:1445-1452.

2. Collins, M. D., D. N. Love, J. Karjalainen, A. Kanervo, B. Forsblom, A. Willems, S. Stubbs, E. Sarkiala, G. D. Bailey, D. I. Wigney, and H. JousimesSomer. 1994. Phylogenetic analysis of members of the genus Porphyromonas and description of Porphyromonas cangingivalis sp. nov. and Porphyromonas cansulci sp. nov. Int. J. Syst. Bacteriol. 44:674-679.

3. Collins, M. D., and H. N. Shah. 1986. Reclassification of Bacteroides praeacutus Tissier (Holdeman and Moore) in a new genus Tissierella as Tissierella praeacuta comb. nov. Syst. Appl. Microbiol. 36:461-463.

4. Collins, M. D., H. N. Shah, and T. Mitsuoka. 1985. Reclassification of Bacteroides microfusus (Kaneuchi and Mitsuoka) in a new genus Rikenella, as Rikenella microfusus comb. nov. Syst. Appl. Microbiol. 6:79-81.

5. Coykendall, A. L., F. S. Kaczmarek, and J. Slots. 1980. Genetic heterogeneity in Bacteroides asaccharolyticus (Holdeman and Moore 1970) Finegold and Barnes 1977 (Approved Lists, 1980) and proposal of Bacteroides gingivalis sp. nov. and Bacteroides macacae (Slots and Genco) comb. nov. Int. J. Syst. Bacteriol. 30:559-564.

6. Finegold, S. M., and E. M. Barnes. 1977. Report of the ICSB Taxonomic Subcommittee on Gram-Negative Anaerobic Rods. Int. J. Syst. Bacteriol. 27:388-391.

7. Hirasawa, M., and K. Takada. 1994. Porphyromonas gingivicanis sp. nov. and Porphyromonas crevioricanis sp. nov., isolated from beagles. Int. J. Syst. Bacteriol. 44:637-640. 
8. Holdeman, L. V., R. W. Kelley, and W. E. C. Moore. 1984. Genus Bacteroides, p. 604-631. In N. R. Krieg and J. G. Holt (ed.), Bergey's manual of systematic bacteriology, vol. 1. The Williams \& Wilkins Co., Baltimore.

9. Holdeman, L. V., and W. E. C. Moore. 1974. Gram-negative anaerobic bacteria, p. 384-404. In R. E. Buchanan and N. E. Gibbons (ed.), Bergey's manual of determinative bacteriology, 8th ed. The Williams \& Wilkins Co., Baltimore.

10. Holdeman, L. V. H., E. P. Cato, and W. E. C. Moore. 1977. Anaerobe laboratory manual update, 4th ed. Virginia Polytechnic Institute and State University, Blacksburg.

11. Johnson, J. L., and L.V. Holdeman. 1983. Bacteroides intermedius comb. nov. and descriptions of Bacteroides corporis sp. nov. and Bacteroides levii sp. nov. Int. J. Syst. Bacteriol. 33:15-25.

12. Lev, M., K. C. Keudell, and A. F. Milford. 1971. Succinate as a growth factor for Bacteroides melaninogenicus. J. Bacteriol. 108:175-178.

13. Lev, M., and A. F. Milford. 1972. Effect of vitamin K depletion and restoration on sphingolipid metabolism in Bacteroides melaninogenicus. J. Lipid Res. 13:364-370.

14. Lev, M. and A. F. Milford. 1973. The 3-ketodihydrosphingosine synthetase of Bacteroides melaninogenicus: induction by vitamin K. Arch. Biochem. Biophys. 157:500-508.

15. Lev, M., and A. F. Milford. 1975. Sensitivity of a Bacteroides melaninogenicus strain to monosaccharides: effect on enzyme induction. J. Bacteriol. 121:152159.

16. Lev, M., and A. F. Milford. 1981. The 3-ketodihydrosphingosine synthetase of Bacteroides melaninogenicus: partial purification and properties. Arch. Biochem. Biophys. 212:424-431.

17. Love, D. N. 1995. Porphyromonas macacae comb. nov., a consequence of Bacteroides macacae being a senior synonym of Porphyromonas salivosa. Int. J. Syst. Bacteriol. 45:90-92.

18. Love, D. N., G. D. Bailey, S. Collings, and D. A. Briscoe. 1992. Description of Porphyromonas circumdentaria sp. nov. and reassignment of Bacteroides salivosus (Love, Johnson, Jones, and Calverley 1987) as Porphyromonas (Shah and Collins 1988) salivosa comb. nov. Int. J. Syst. Bacteriol. 42:434438.

19. Love, D, No, J. Karjalainen, A. Kanervo, B. Forsblom, E. Sarkiala, G. D. Bailey, D. I. Wigney, and H. Jousimies-Somer. 1994. Porphyromonas canoris sp. nov., an asaccharolytic, black-pigmented species from the gingival sulcus of dogs. Int. J. Syst. Bacteriol. 44:204-208.

20. Montgomery, L. B. Flesher, and D. Stahl. 1988. Transfer of Bacteroides succinogenes (Hungate) to Fibrobacter gen. nov. as Fibrobacter succinogenes comb. nov. and description of Fibrobacter intestinalis sp. nov. Int. J. Syst. Bacteriol. 38:430-435.

21. Moore, L. V. H., and W. E. C. Moore. 1994. Oribaculum catoniae gen. nov.; Catonella morbi gen. nov., sp. nov.; Hallella seregens gen. nov., sp. nov.; Johnsonella ignava gen. nov., sp. nov.; and Dialister pneumosintes gen. nov., comb. nov., nom. rev., anaerobic gram negative bacilli from the human gingival crevice. Int. J. Syst. Bacteriol. 44:187-192.

22. Paster, B. J., and F. E. Dewhirst. 1988. Phylogeny of campylobacters, wolinellas, Bacteroides gracilis, and Bacteroides ureolyticus by $16 \mathrm{~S}$ ribosomal ribonucleic acid sequencing. Int. J. Syst. Bacteriol. 38:56-62.

23. Paster, B. J., F. E. Dewhirst, I. Olsen, and G. J. Fraser. 1994. Phylogeny of Bacteroides, Prevotella, and Porphyromonas spp. and related bacteria. J. Bacteriol. 176:725-732.

24. Paster, B. J., W. Ludwig, W. G. Weisburg, E. Stackebrandt, R. B. Hespell, C. M. Hahn, H. Rechenbach, K. O. Stetter, and C. R. Woese. 1985. A phylogenetic grouping of Bacteroides, cytophagas and certain flavobacteria. Syst. Appl. Microbiol. 6:34-42.

25. Shah, H. N. 1992. The genus Bacteroides and related species, p. 3593-3607. In A. Balows, H. G. Trüper, M. Dworkin, W. Harder, and K.-H. Schleifer (ed.), The prokaryotes, 2nd ed. Springer-Verlag, New York.

26. Shah, H. N. 1992. The genus Porphyromonas, p. 3608-3619. In A. Balows, H. G. Trüper, M. Dworkin, W. Harder, and K.-H. Schleifer (ed.), The prokaryotes, 2nd ed. Springer-Verlag, New York.

27. Shah, H. N., and M. D. Collins. 1980. Fatty acid and isoprenoid quinone composition in the classification of Bacteroides metaninogenicus and related taxa. J. Appl. Bacteriol. 48:75-87.

28. Shah, H. N., and M. D. Collins. 1982. Reclassification of Bacteroides hypermegas (Harrison and Hansen) in a new genus Megamonas, as Megamonas hypermegas comb. nov. Zentralbl. Bakteriol. Parasitenkd. Infektionskr. Hyg Abt. 1 Orig. Reihe C 3:394-398.

29. Shah, H. N., and M. D. Collins. 1982. Reclassification of Bacteroides multiacidus (Mitsuoka, Terada, Watanabe and Uchida) in a new genus Mitsuokella, as Misuokella multiacidus comb. nov. Zentralbl. Bakteriol. Parasitenkd. Infektionskr. Hyg. Abt. 1 Orig. Reihe C 3:491-494.

30. Shah, H. N., and M. D. Collins. 1983. Genus Bacteroides: a chemotaxonomical perspective. J. Appl. Bacteriol. 55:403-416.

31. Shah, H. N., and M. D. Collins. 1986. Reclassification of Bacteroides termitidis (Sebald) in a new genus Sebaldella, as Sebaldella termitidis comb. nov. Int. J. Syst. Bacteriol. 36:349-350.

32. Shah, H. N., and M. D. Collins. 1986. Reclassification of Bacteroides furcosus Veillon and Zuber (Hauduroy, Ehringer, Urbain, Guillot and Magron) in a new genus Anaerorhabdus, as Anaerorhabdus furcosus comb. nov. Syst. Appl. Microbiol. 8:86-88.

33. Shah, H. N., and M. D. Collins. 1988. Proposal for reclassification of Bacteroides asaccharolyticus, Bacteroides gingivalis, and Bacteroides endodontalis in a new genus, Porphyromonas. Int. J. Syst. Bacteriol. 38:128-131.

34. Shah, H. N., and M. D. Collins. 1989. Proposal to restrict the genus Bacteroides (Castellani and Chalmers) to Bacteroides fragilis and closely related species. Int. J. Syst. Bacteriol. 39:85-87.

35. Shah, H. N., and M. D. Collins. 1990. Prevotella, a new genus to include Bacteroides melaninogenicus and related species formerly classified in the genus Bacteroides. Int. J. Syst. Bacteriol. 40:205-208.

36. Shah, H. N., T. J. M. van Steenbergen, J. M. Hardie, and J. de Graaf. 1982 DNA base composition, DNA-DNA reassociation and isoelectric-focusing of proteins of strains designated Bacteroides oralis. FEMS Microbiol. Lett. 13:125-130.

37. Shah, H. N., and R. A. D. Williams. 1982. Dehydrogenase patterns in the taxonomy of Bacteroides. J. Gen. Microbiol. 128:2955-2965.

38. Shah, H. N., R. A. D. Williams, G. H. Bowden, and J. M. Hardie. 1976 Comparison of the biochemical properties of Bacteroides melaninogenicus from human dental plaque and other sites. J. Appl. Microbiol. 41:473-492.

39. Slots, J., and R. J. Genco. 1980. Bacteroides melaninogenicus subsp. macacae a new subspecies from monkey periodontopathic indigenous microflora. Int J. Syst. Bacteriol. 30:82-85.

40. Stackebrandt, E., and H. Hippe. 1986. Transfer of Bacteroides amylophilus to a new genus Ruminobacter gen. nov., nom. rev. as Ruminobacter amylophilus comb. nov. Syst. Appl. Microbiol. 8:204-207.

41. van Steenbergen, T. J. M., A. J. van Winkelhoff, D. Mayrand, D. Grenier, and J. de Graafi. 1984. Bacteroides endodontalis sp. nov., an asaccharolytic blackpigmented Bacteroides species from infected dental root canals. Int. J. Syst. Bacteriol. 34:118-120. 